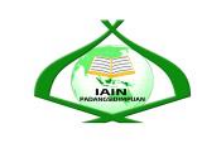

At-Tijaroh : Jurnal Ilmu Manajemen dan Bisnis Islam

Volume 5 Nomor 1 Ed. Jan - Juni 2019 : Hal 01 - 17

p-ISSN : $2356-492 x$

e-ISSN : $2549-9270$

\title{
KOMUNIKASI PEMASARAN ONLINE DAFFI HIJAB STYLE LAMONGAN
}

\author{
M. Zaimil Fanani ${ }^{1}$, Redi Panuju ${ }^{2}$ \\ 1,2Universitas dr Soetomo Surabaya \\ 1,2Jl. Semolowaru No.48, Menur Pumpungan Kec. Sukolilo, Surabaya, Jawa Timur \\ Email : redipanuju@gmail.com
}

\begin{abstract}
This research discusses about a garment company that its products sell through online marketing. Today's fashion sales have used internet because of the ease of transactions, which saves time. Daffi Hijab was one of the fashion producers that uses online marketing with the type of product being marketed is syar'i hijab. The advantages of Daffi Hijab are using beautiful, tall and slender brand ambassadors for Muslim women. This research is a qualitative approach, where data is obtained through observations on the online media used, messages delivered, and ways of marketing, as well as conducting special interviews with the marketing management team of Daffi Hijab. The results showed that Daffi Hijab had used marketing mix techniques and had collaborated with partnership services and social programs, which were informed through online media.
\end{abstract}

Keyword : Communication, Online Marketing, Hijab

\begin{abstract}
Abstrak
Penelitian ini membahas tentang sebuah perusahan di bidang garment yang memasarkan produknya melalui pemasaran online. Penjualan fashion sekarang ini sudah banyak menggunakan bantuan internet karena kemudahan dalam bertransaksi sehingga menghemat waktu. Daffi Hijab merupakan salah satu produsen fashion yang menggunakan pemasaran online dengan jenis produk yang dipasarkan adalah hijab syar'i. Keunggulan Daffi Hijab yakni menggunakan brand ambassador muslimah yang cantik, tinggi, dan semampai. Penelitian ini merupakan penelitian dengan pendekatan kualitatif, yang mana data diperoleh melalui observasi pada media online yang digunakan, pesan yang disampaikan, dan cara pemasarannya, serta melakukan wawancara khusus pada tim manajemen pemasaran Daffi Hijab. Hasil penelitian menunjukkan bahwa Daffi Hijab telah menggunakan teknik bauran pemasaran dan telah bekerjasama dengan layanan kemitraan dan program-program sosial, yang diinformasikan melalui media online.
\end{abstract}

Kata Kunci : Komunikasi, Pemasaran Online, hijab.

\section{PENDAHULUAN}

Teknologi pada saat ini berkembang sangat cepat terutama teknologi dibidang informasi komunikasi, sehingga masyarakat mendapatkan kemudahan serta kecepatan dalam mengakses informasi yang dibutuhkan, dengan adanya perkembangan teknologi informasi 


\section{2 | Komunikasi Pemasaran Online Daffi Hijab Style Lamongan}

tersebut, manusia semakin mudah melakukan kegiatan berkomunikasi, dan secara tidak langsung manusia telah menjadi masyarakat informasi.

Konsep masyarakat informasi muncul pada tahun 1970-an, dimana pada saat itu terjadi peralihan dari masyarakat industri menuju masyarakat informasi. Masyarakat informasi adalah masyarakat yang menjadikan informasi sebagai komoditas ekonomi yang sangat berharga, berhubungan dengan masyarakat lain dalam sistem komunikasi global, dan mengakses informasi super highway (Abrar, 2003).

Teknologi informasi menjadikan seseorang tidak harus melakukan komunikasi secara langsung dengan bertatap muka. Kini percakapan antara manusia tidak selalu dengan lisan, namun bisa melalui tulisan. Selain melalui media telepon genggam yang dapat mengirim pesan secara lisan maupun tulisan, kini hal tersebut juga dapat dilakukan melalui internet (International Network). Internet merupakan sekumpulan jaringan yang berskala global (Sarwono, 2008). Internet juga mampu menciptakan hubungan menjadi lebih dekat dan menghemat waktu antar individu baik yang dekat maupun yang jauh. Banyak fitur internet yang berfungsi untuk memuaskan kebutuhan khalayak, seperti membahas music, film, fashion, games, bahkan berita ter-update secara cepat dikarenakan jaringan internet yang mudah diakses dari mana saja.

Internet telah menjadi media yang terus berkembang fungsinya, tidak hanya sebagai media informasi tetapi juga sebagai media pemasaran dan media komunikasi. Menurut data terbaru yang dirilis We Are Social per Agustus 2017, jumlah pengguna internet global kini menyentuh angka 3,8 miliar dengan penetrasi 51 persen dari total populasi di dunia. Laporan Tetra Pak Index 2017 yang belum lama diluncurkan, mencatatkan ada sekitar 132 juta pengguna internet di Indonesia. Sementara hampir setengahnya adalah penggila media sosial, atau berkisar dengan angka 40\%. Penetrasi internet yang begitu besar dan semakin pesatnya peningkatan infrastruktur internet di Indonesia, memicu pertumbuhan progresif pada sistem penjualan online atau yang biasa disebut dengan bisnis online.

Komunikasi pemasaran merupakan salah satu awal dalam rangka mengenalkan produk pada konsumen, dan ini akan menjadi sangat penting karena akan berkaitan dengan keuntungan yang akan diperoleh oleh penjual. Seperti yang terlihat, internet merupakan media pemasaran yang tepat untuk mendekat kepada khalayak. Banyak sekali penawaran penjualan produk yang diberikan bisnis online melalui internet, baik produk lokal maupun internasional, dari harga yang murah hingga yang paling mahal. Bisnis online juga menawarkan berbagai kebutuhan khalayak, antara lain pakaian, barang elektronik, tas, sepatu dan jenis barang lainnya, yang ditawarkan untuk kepuasan masyarakat yang ingin berbelanja dengan cepat dan mudah tanpa harus pergi keluar rumah.

Sistem bisnis online lebih mudah untuk dilakukan dan tidak memerlukan investasi yang besar, baik diawal maupun ketika pengoperasiannya. Hanya membutuhkan koneksi internet 
yang bagus sebagai modal awal untuk membangun bisnis online ini. Sifat pasar online yang sangat dinamis dan menuntut perubahan-perubahan cepat, membutuhkan reaksi dan langkah yang tepat agar sebuah produk maupun jasa dapat bertahan dan memenangkan persaingan. Komunikasi pemasaran menjadi alat yang penting dan mulai diperhitungkan dengan serius dalam sistem pemasaran online untuk menjawab tantangan-tantangan tersebut, dimana cara penyampaian ke konsumen menjadi hal yang sangat penting.

Saat ini mayoritas barang atau produk yang menjadi andalan bisnis online adalah produk-produk berkaitan dengan gaya hidup (lifestyle) seperti fashion dan clothing, produk kecantikan dan kesehatan, serta teknologi dan gadget. Bisnis online sendiri selain menggunakan platform milik pribadi seperti website, juga menggunakan platform sosial media dalam memasarkan produk-produk dan jasanya. Salah satu platform sosial media yang paling popular adalah Facebook dan Twitter. Menurut laporan riset We Are Social dan Hootsuite, Indonesia menduduki peringkat ke-4 di dunia dengan pengguna Facebook paling aktif. Hal ini diungkap dari yang dirilis di LinkedIn. Ditambah dengan penggunaan aplikasi online dalam pemasaran berbasis daring, menjadi semakin memudahkan transaksi pemasaran (Ronny, NF dan Panuju, R, 2018).

Banyak sekali keuntungan-keuntungan yang didapat dari berbelanja online ini. Keuntungan pertama adalah Bisnis online dapat diakses kapan saja 24 jam dalam sehari jika dibandingkan dengan toko-toko yang hanya beroperasi pada jam kerja, belum lagi membutuhkan waktu dan juga tenaga untuk mencapai toko yang diinginkan, belanja online benar-benar mempunyai nilai lebih dimata para konsumen, selain itu keuntungan dari belanja online yakni harga barang-barangnya relatif lebih murah.

Fashion hijab Indonesia kini tidak hanya menjadi tren fashion di dalam negeri, tapi juga menjadi tren luar negeri dan manca negara. Karena sangat banyak designer hijab Indonesia yang menghasilkan tren-tren fashion hijab yang baru secara terus-menerus. Menurut Dirjen Industri Kecil Menengah (IKM) Kementerian Perindustrian, Euis Saidah, terdapat 20 juta penduduk Indonesia yang menggunakan hijab. Hal ini selaras dengan perkembangan industri fashion muslim tujuh persen setiap tahun. Tak heran kalau Asosiasi Perancang Pengusaha Mode Indonesia (APPMI) bermimpi dapat mengembangkan fashion muslim Indonesia tak hanya di dalam negeri, bahkan sampai ke tingkat dunia. (Ramadhani, kompasiana, dikutip tanggal 09/10/2018).

Dalam beberapa tahun belakangan ini, bisnis kerudung memang mengalami perkembangan yang cukup pesat. Hal ini dikarenakan adanya pergeseran budaya dimana kerudung atau hijab tidak semata-mata menunjukkan status atribut suatu agama tertentu, yang mana dalam ajaran Islam menutup aurat untuk perempuan wajib hukumnya, selain menjadi status atribut agama, kerudung atau hijab juga menjadi atribut sosial (fashion), yang dulunya model kerudung tampil monoton dengan warna netral, kini model dan warna 


\section{4 | Komunikasi Pemasaran Online Daffi Hijab Style Lamongan}

semakin bervariasi dan modis. Bahkan, seperti yang telah digambarkan di atas, kini hijab menjadi trend mode yang cukup diperhitungkan dikalangan mode Indonesia.

Daffi Hijab merupakan salah satu dari brand kerudung yang bermain di pasar online yang dewasa ini sedang mengalami pertumbuhan pesat. Mengawali bisnisnya di tahun 2014 dari situs Daffi Hijab @suplaierkerudungsegiempat, berkembang dengan memiliki official website sendiri www.daffihijab.id.

Brand Daffi Hijab Style dari yang tidak dikenal oleh konsumen sampai memiliki konsumen-konsumen loyal merupakan suatu pencapaian yang tidak mudah dan diperlukan pemikiran serta pola komunikasi yang tepat sehingga dapat meningkatkan awareness pada konsumen akan keberadaan brand Daffi Hijab dalam menawarkan produk-produk kerudungnya. Brand awareness atau Kesadaran Merek mengacu pada sejauh mana pelanggan dapat mengingat atau mengenali merek. Kesadaran merek merupakan pertimbangan utama dalam perilaku konsumen (consumer behavior), manajemen periklanan (advertising management), manajemen merek (brand management) dan pengembangan strategi. Penelitian ini dilakukan untuk mengetahui bagaimana komunikasi pemasaran online yang dilakukan oleh Daffi Hijab Lamongan.

\section{TINJAUAN TEORITIK}

\subsection{Komunikasi Pemasaran}

Komunikasi pemasaran dapat dijelaskan dengan memahami dua unsur, yaitu komunikasi dan pemasaran. Komunikasi pada hakekatnya adalah proses penyampaian pesan antara seseorang kepada orang lain melalui penggunaan media dengan tujuan agar orang yang menerima pesan memahami secara baik dan terjadi perubahan perolaku sesuai yang diharapkan dalam pesan.

Menurut (Tjiptono, 1997) Komunikasi pemasaran adalah aktivitas pemasaran yang berusaha menyebarkan informasi, mempengaruhi, membujuk dan mengingatkan pasar sasaran atas perusahaan dan produknya agar bersedia menerima, membeli dan loyal pada produk yang ditawarkan.

Komunikasi Pemasaran adalah proses dialog yang berkelanjutan (the continuing dialogue) antara pembeli dan penjual dalam suatu tempat pemasar (market place). Komunikasi pemasaran merupakan pertukaran informasi dua arah antara pihak atau lembaga-lembaga yang terlibat dalam pemasaran (Bulaeng, 2002).

Hingga saat ini definisi yang tepat untuk komunikasi pemasaran masih simpang siur. Akan tetapi pada akhirnya, banyak akademisi dan praktisi 
mendefinisikan komunikasi pemasaran adalah sebagai berikut: "Semua elemen-elemen promosi dari marketing mix yang melibatkan komunikasi antar organisasi dan target audience pada segala bentuknya yang ditujukan untuk performance pemasaran" (Prisgunanto, 2006).

Warren J. Keegan (1995) mendefinisikan komunikasi pemasaran ialah semua elemen dalam pemasaran yang memberi arti dan mengkomunikasikan nilai kepada konsumen dan stakeholder sebuah perusahaan (Machfoedz, 2010). Komunikasi pemasaran adalah kegiatan komunikasi yang dilakukan oleh pembeli dengan penjual dan merupakan kegiatan yang membantu dalam pengambilan keputusan dibidang pemasaran serta mengarahkan pertukaran agar lebih memuaskan dengan cara menyadarkan semua pihak untuk berbuat lebih baik (Sutisna, 2002). Tujuan utama dalam komunikasi pemasaran adalah mempengaruhi. Komunikasi dimaksud untuk menginformasikan, mendidik, menciptakan kesaradan, minat, kebutuhan atau hasrat atas sebuah produk (Zhoriva \& Williams,).

Model komunikasi konvensional merupakan dasar bagi komunikasi pemasaran. Gambar 1 berikut merupakan model yang telah disesuaikan dengan konteks pemasaran:

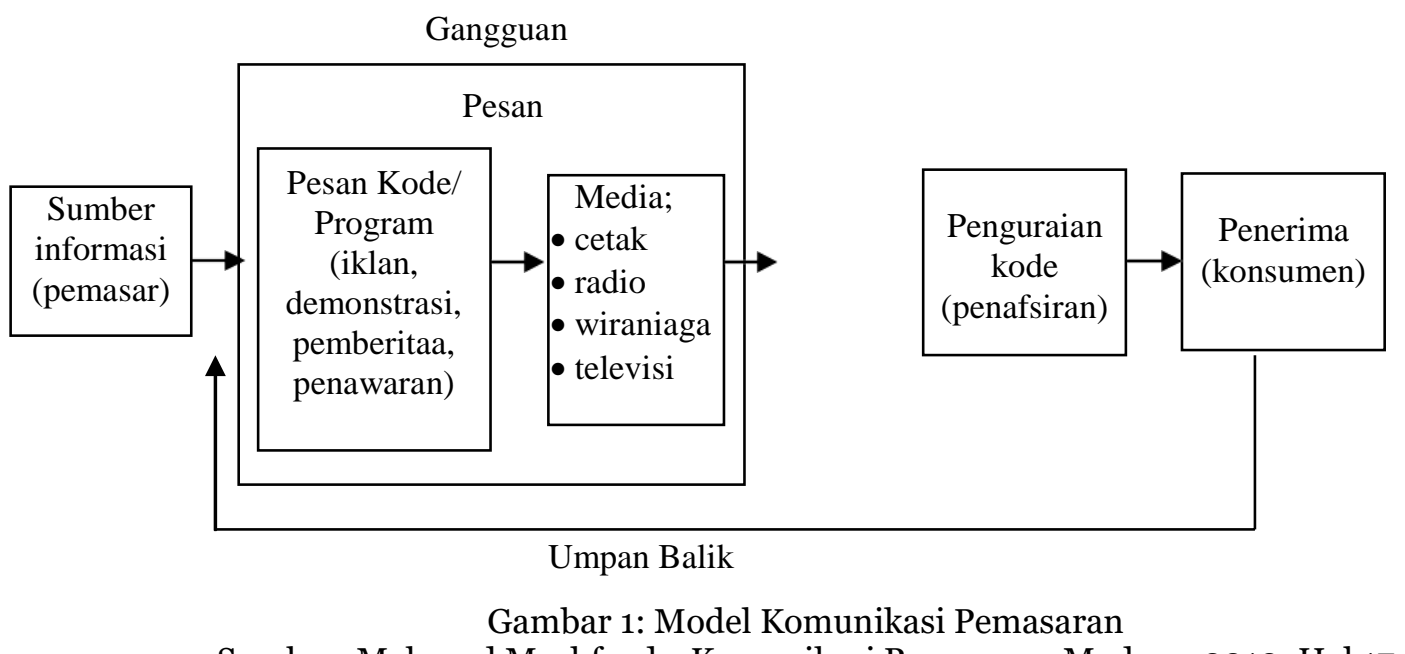

Sumber: Mahmud Machfoedz. Komunikasi Pemasaran Modern. 2010. Hal 17

Uraian berikut menjelaskan unsur-unsur yang merupakan tahapan dalam proses komunikasi:

a. Sumber Informasi. Sumber informasi ialah pemasar (perusahaan atau organisasi) 
b. Kode/Program. Adalah proses pembentukan pesan atau ide ke dalam bentuk yang dapat dipahami dan diharapkan dapat mempengaruhi penerima. Tahapan ini mencerminkan strategi kreatif atau saran penjual, janji yang dibuat oleh perusahaan tentang produk atau perusahaannya.

c. Pesan. Pesan adalah pelaksanaan strategi kreatif. Pesan dapat diungkapkan dengan berbagai cara, meliputi kata-kata (secara lisan atau tertulis), diagram, gambar, dan dramatisasi dalam berbagai bentuk.

d. Media. Adalah saluran yang digunakan untuk mengkomunikasikan pesan, seperti radio, televisi, media cetak, telepon dan hubungan langsung antara wiraniaga dan konsumen, atau kata-kata yang diucapkan oleh konsumen.

e. Penguraian kode. Adalah penafsiran pesan oleh penerima. Pesan yang sama dapat ditafsirkan berbeda oleh penerima yang beragam, yang mempunyai pengalaman, pengetahuan, dan lingkungan masing-masing.

f. Penerima. Yaitu pihak yang menerima pesan, perusahaan, konsumen, atau stakeholder pengirim pesan yang ingin mempengaruhi dengan cara tertentu.

g. Umpan balik. Respons penerima terhadap pesan, yang diharapkan oleh pemasar akan dapat mengubah sikap atau perilaku atau permintaan informasi yang lebih rinci.

Dalam seluruh komunikasi pemasaran, "gangguan" dapat membaur dengan desain, penyampaian, atau penerimaan pesan. Gangguan ialah segala sesuatu yang bersifat fisik dan psikologis, yang berbaur dalam cara yang dilakukan untuk melaksanakan kreasi, penyampaian, penerimaan, dan penafsiran pesan pemasaran (Machfoedz, 2010).

Periklanan merupakan salah satu bentuk khusus komunikasi untuk memenuhi fungsi suatu pemasaran, maka apa yang harus dilakukan dalam kegiatan periklanan tentu saja harus lebih dari sekedar memberikan informasi kepada khalayak (Jefkins, 1995).

Perencanan pemasaran secara umum terdiri atas lima elemen utama, yaitu harus tersedia suatu analisis situasi (situasion analysis) yang terperinci yang terdiri atas hasil audit pemasaran internal (internal marketing audit) serta analisis eksternal mengenai persaingan pasar dan faktor-faktor lingkungan yang mempengaruhi, harus tersedia tujuan pemasaran spesifik yang memberikan arahan dan tahapan kerja (time frame) bagi pelaksana kegiatan pemasaran serta tolak ukur untuk mengukur kinerja yang dicapai, 
harus terdapat keputusan mengenai pemilihan atau seleksi pasar sasaran (target market) dan keputusan terhadap empat elemen dalam marketing mix, harus terdapat program untuk melaksanakan keputusan yang sudah dibuat termasuk penentuan tugas atau pekerjaan yang akan dilakukan serta bentuk pertanggung jawabannya, harus terdapat suatu proses monitoring, proses evaluasi terhadap kinerja dan juga proses pemberian umpan balik. Setiap perubahan yang diperlukan dapat dilakukan dalam keseluruhan strategi dan taktik pemasaran (Morissan, 2010).

\subsection{Teori IMC (Integrated Marketing Communication)}

Kotler dan Amstrong (1997) mengatakan, IMC atau Komunikasi pemasaran terpadu adalah proses pengembangan dan implementasi berbagai bentuk program komunikasi persuasif kepada pelanggan dan calon pelanggan secara berkelanjutan. Tujuan IMC adalah untuk mempengaruhi atau memberikan efek langsung kepada perilaku khalayak sasaran yang dimilikinya. IMC menganggap seluruh sumber yang dapat menghubungkan pelanggan atau calon pelanggan dengan produk atau jasa dari suatu merek atau perusahaan, adalah jalur potensial untuk menyampaikan pesan dimasa datang. Lebih jauh lagi, IMC menggunakan bentuk komunikasi yang relevan serta yang dapat diterima oleh pelanggan dan calon pelanggan dengan kata lain, proses IMC berawal pelanggan atau calon pelanggan, kemudian berbalik kepada perusahaan untuk menentukan dan mendefinisikan bentuk dan metode yang perlu dikembangkan bagi program komunikasi yang persuasive.

Lebih lanjut Terrance A. Shimp (2003) menjelaskan IMC memiliki beberapa ciri utama yakni:

\section{a. Mempengaruhi Perilaku}

Tujuan dari IMC adalah menggerakkan orang untuk mengambil tindakan. IMC bertujuan mempengaruhi prilaku khalayak agar memiliki kesadaran terhadap sebuah merek yang sedang dipasarkan, kemudian menanamkan nilai-nilai positif (mendukung) produk tersebut dan diharapkan berujung pada penggunaan merek (konsumsi).

\section{b. Berawal Dari Pelanggan dan calon pelanggan}

Ciri kedua IMC yakni berawal dari pelanggan. Maksudnya pendekatan itu dimulai dengan melihat apa yang dibutuhkan oleh khalayak. Kemudian perusahaan selaku pemasar (komunikator) menyesuaikan bentuk 
komunikasi yang digunakan untuk memenuhi apa yang diinginkan pelanggan atau calon pelanggan.

c. Melakukan satu atau berbagai cara untuk melakukan kontak

Dalam prosesnya, IMC menggunakan seluruh bentuk komunikasi yang tersedia dan seluruh kontak yang bisa menghubungkan merek dengan pelanggan sebagai jalur penyampaian pesan. Kontak disini dimaksudkan sebagai saluran atau media penyampaian informasi.

d. Berusaha menciptakan sinergi

IMC membutuhkan sinergi antar semua elemen komunikasi yang digunakan dalam proses komunikasi pemasaran tersebut. Karena jika satu elemen saja tidak berjalan secara padu sinergi tersebut tidak akan tercapai.

\section{e. Menjalin hubungan}

Karakteristik yang terakhir dari IMC adalah komunikasi pemasaran yang sukses membutuhkan terjalinnya komunikasi atau hubungan antara merek dengan pelanggannya secara berkesinambungan.

\section{METODE PENELITIAN}

\subsection{Daffi Hijab Lamongan}

Daffi Hijab merupakan brand kerudung yang baru dirintis, namun mengalami perkembangan yang sangat pesat, berpusat di Desa Tugu Kecamatan Mantub Kabupaten Lamongan Provinsi Jawa timur. Daffi Hijab adalah salah satu brand Hijab yang memilih jalur online dalam memasarkan produk-produknya.

\subsection{Tipe Penelitian}

Dalam penelitian ini, peneliti menggunakan tipe Kualitatif. Penelitian kualitatif bertujuan untuk menjelaskan fenomena dengan sedalamdalamnya melalui pengumpulan data sedalam-dalamnya (Kriyantono, 2009).

(Moleong, 2006) mengungkapkan bahwa pendekatan kualitatif tidak mengumpulkan data berupa angka, sehingga tujuan penelitian kualitatif adalah penggambaran secara mendalam, terperinci dan tuntas mengenai realita empiris dibalik sebuah fenomena. 


\subsection{Teknik Pengumpulan Data}

Di dalam penelitian kualitatif, pengumpulan data merupakan hal yang esensial. Pengumpulan data penelitian kualitatif tidak mengumpulkan data melalui instrument yang dibuat untuk mengukur variabel-variabel penelitian, seperti dalam penelitian kuantitatif. Namun pengumpulan data penelitian kualitatif, peneliti merupakan instrument data penelitian kualitatif, peneliti berinteraksi secara simbolik dengan informan/subjek yang diteliti. (Iskandar, 2009)

Pengumpulan data dalam penelitian kualitatif dapat dilakukan oleh peneliti dengan menggunakan beberapa teknik pengumpulan data. Metode yang digunakan untuk mengumpulkan data dalam penelitian Komunikasi Pemasaran Online Daffi Hijab Lamongan terbagi menjadi dua jenis yaitu:

a. Data primer, yakni data yang diperoleh langsung dari lapangan. Adapun metode pengumpulan data primer adalah sebagai berikut:

b. Wawancara Mendalam (In depth interview), wawancara mendalam (in depth interview) dilakukan dalam konteks observasi partisipasi dimana peneliti terlibat secara intensif dengan setting penelitian terutama keterlibatan dengan subjek penelitian. (Iskandar, 2009).

Mc. Milan \& Schumacher (2001) dalam Satori \& Komariah (2010) wawancara mendalam merupakan Tanya jawab yang terbuka untuk memperoleh data tentang maksud hati partisipan yang bagaimana menggambarkan kejadian-kejadian, atau fenomena-fenomena yang berhubungan dengan setting penelitian. Dengan cara dialog antara peneliti sebagai pewawancara dengan informan. Informan yang akan peneliti wawancara adalah Luthfi Anshori dan Hadiatur Rusdah, selaku owner dari subjek yang diteliti, yaitu Daffi Hijab Style, kemudian Albert Suryansyah, Bagian Pemasaran Daffi Hijab Style, dan Yulia Dwi Erinda, serta Dewi Fajar Dining Aprilia selaku Konsumen Produk Daffi Hijab Style. Pada penelitian ini, wawancara dilakukan dengan mengajukan beberapa pertanyaan yang berhubungan dengan objek penelitian, yaitu Komunikasi Pemasaran Online dari subjek Daffi Hijab Lamongan.

c. Observasi, Observasi merupakan teknik pengumpulan data melalui pengamatan terhadap suatu obyek atau peristiwa. Tujuan dari observasi ini adalah agar peneliti merasakaan dan memahami suatu obyek atau 
peristiwa berdasarkan pengetahuaan dan gagasan yang telah dimiliki dan untuk mendapatkan informasi yang dibutuhkan untuk melanjutkan penelitian. Observasi yang dilakukan dalam penelitian ini menggunakan observasi tidak terstruktur yaitu teknik observasi yang biasa digunakan dalam penelitian kualitatif.

d. Data sekunder, yaitu data yang diperoleh dengan memanfaatkan berbagai macam data, diantaranya adalah data-data yang ada di dalam media online yang digunakan oleh Daffi Hijab Lamongan, seperti Facebook, Instagram dan Youtube. Disamping itu, data sekunder.

\subsection{Teknik Analisis Data}

Teknik analisis data yang digunakan dalam penelitian ini adalah analisis model alir, yang mengacu pada teori Miles dan Huberman. Melakukan analisis data artinya melakukan kajian untuk memahami struktur suatu fenomena-fenomena yang berlaku di lapangan. Dalam penelitian kualitatif deskriptif ini, metode analisis yang data yang digunakan adalah analisis metode Miles dan Huberman dalam buku (Iskandar, 2009) terdapat tiga langkah yang harus dilakukan, yaitu:

\section{a. Reduksi Data}

Reduksi data merupakan proses pengumpulan data penelitian, seorang peneliti dapat menemukan kapan saja waktu untuk mendapatkan data yang banyak, apabila peneliti mampu menerapkan metode observasi, wawancara, atau dari berbagai dokumen yang berhubungan dengan subjek yang diteliti. (Iskandar, 2009).

Dalam pelaksanaan penelitian, peneliti mencatat kegiatan secara tertulis di lapangan yang berlangsung di Daffi Hijab Lamongan. Dalam penelitian ini peneliti melakukan pemilihan data sesuai dengan tujuan dan memusatkan penelitian, yaitu untuk mengetahui Komunikasi Pemasaran online Daffi Hijab Lamongan.

b. Display atau Penyajian Data

Penyajian data kepada yang telah diperoleh ke dalam sejumlah matriks atau daftar kategori setiap data yang didapat, penyajian data biasanya digunakan berbentuk teks naratif. Dalam penyajian data peneliti dapat dianalisis oleh peneliti untuk disusun secara sistematis, 
atau simultan sehingga data yang diperoleh dapat menjelaskan atau menjawab masalah yang diteliti. (Iskandar, 2009).

Dalam penyajian data ini dari seluruh data di lapangan berupa hasil wawancara, observasi, maupun dokumentasi, akan dianalisis sesuai dengan teori-teori yang telah dipaparkan sebelumnya. Sehingga dapat memunculkan deskripsi tentang Komunikasi Pemasaran Online Daffi Hijab Lamongan.

c. Mengambil Kesimpulan lalu diverifikasi

Mengambil kesimpulan merupakan analisis lanjutan dari reduksi data, dan display data sehingga data dapat disimpulkan, dan peneliti masih berpeluang untuk menerima masukan. Peneliti dapat memaparkan kesimpulan dari sudut pandang peneliti untuk lebih mempertegas penulisan penelitian ini. (Iskandar, 2009).

Dalam penelitian ini peneliti mengambil data berdasarkan fakta tentang komunikasi pemasaran online Daffi Hijab Lamongan, kemudian peneliti menyimpulkan instrument pengamatan.

\section{HASIL DAN PEMBAHASAN}

\subsection{Profil Daffi Hijab Style}

Daffi Hijab adalah produsen hijab trendy yang mengedepankan kualitas, penjelasan yang ditemukan ketika membuka website Daffi Hijab. Daffi Hijab Style beralamat di Desa Tugu kecamatan Mantub Kabupaten Lamongan. Daffi Hijab merupakan brand kerudung yang memilih jalur online dalam memasarkan produkproduknya. Daffi Hijab didirikan oleh seorang Ibu muda yang berasal dari Lamongan provinsi Jawa Timur, yakni Khadiatur Rusdah pada bulan Maret 2015. Bisnis online ini dirintis bersama sang suami, yaitu, Luthfi Anshori. Sebelumnya, Rusdah telah merintis bisnis online ini sejak tahun 2013, dengan nama akun facebook Jilbabku Lamongan, penjualan dilakukan dengan cara dropshipper.

Daffi Hijab Style mengalami perkembangan cukup baik dan mulai mempekerjakan puluhan karyawan. Untuk karyawan yang berada di kantor pusat Daffi hijab style, di Desa Tugu Mantub berjumlah 11 orang, terdiri dari bagian gudang 6 orang, admin order 2 orang, admin financial 1 orang, customer service 1 orang, editor foto plus cek stok 1 orang dan dibantu customer service.

Selain karyawan di atas Daffi hijab style juga mengkaryakan 3 kelompok penjahit, yaitu 1 kelompok di Jawa Tengah, 1 kelompok di Jawa Timur, dan 1 kelompok di Bandung. Masing-masing kelompok beranggotakan 10 orang penjahit. 
Daffi Hijab juga menugaskan penyortir sebanyak 7 orang untuk mengecek kualitas jahitan dan bahan.

Disamping karyawan, Daffi Hijab juga membangun kemitraan dengan Agen dan Sub Agen untuk membangun pemasaran produk Daffi Hijab Style. Kini Daffi Hijab Style memiliki 35 Agen, 6o Sub Agen, dan 2369 member.

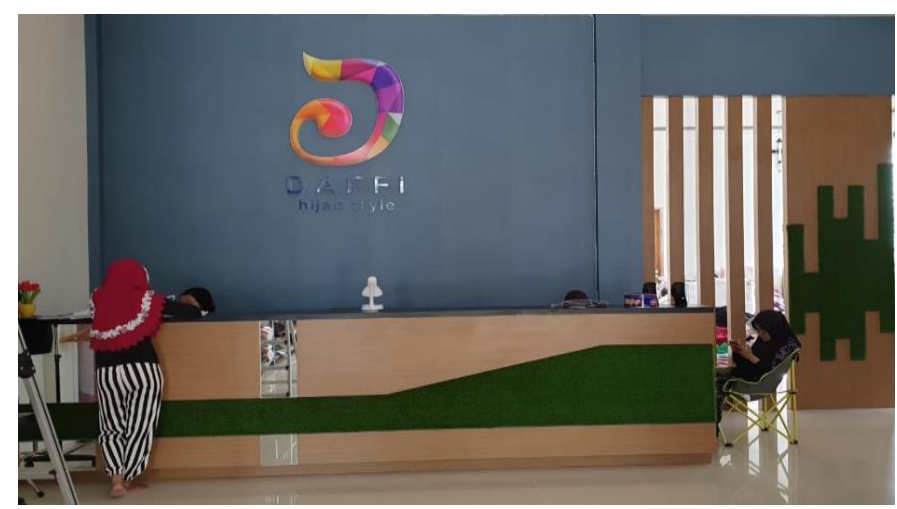

Gambar 2. Toko atau Kantor Pusat Daffi Hijab Style

Modal awal yang dikeluarkan Daffi Hijab Style sebelum mempunyai produk sendiri hanya sebesar Rp. 2.00o.ooo,- untuk belanja kerudung jadi. Sementara untuk modal saat Daffi mulai memproduksi sendiri adalah sebesar Rp 10.000.00o untuk beli bahan mentah dan ongkos penjahit. Sistem pembayaran yang diterapkan oleh Daffi Hijab Style adalah full payment. Pembayaran dilakukan di awal ketika konsumen sudah memilih model kerudung yang ingin dipesan. Pembayaran bisa dilakukan secara tunai maupun transfer. Bisnis yang berawal dari rasa iseng ini kini telah berkembang dan banyak diminati. Hal ini dapat dilihat dari jumlah followers akun Facebook dan Instagram Daffi Hijab Style yang berjumlah 13.840 pengikut Facebook dengan 12.908 like dan followers Instagram sebanyak $34.4 \mathrm{k}$.

\subsection{Hasil Penjualan}

Berdasarkan hasil wawancara, penjualan yang telah dicapai oleh Daffi Hijab Style sejak Maret 2015, yang pada saat itu beromset 400 ribu perminggu, kini omset yang didapat oleh Daffi Hijab Style rata-rata perbulan dapat mencapai Rp. 1.00o.ooo.ooo,- (Satu Milyar Rupiah) sampai dengan Rp. 1.500.000.000,-.(Satu Milyar Lima Ratus Juta Rupiah)

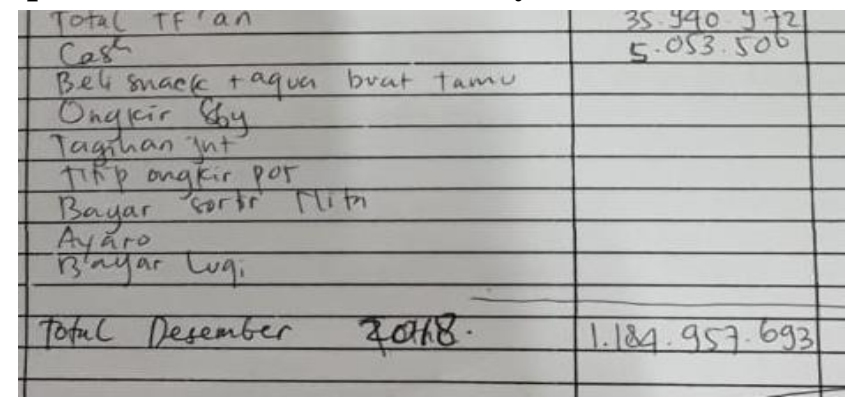

Gambar 3. Laporan Keuangan Daffi bulan Desember 2018 


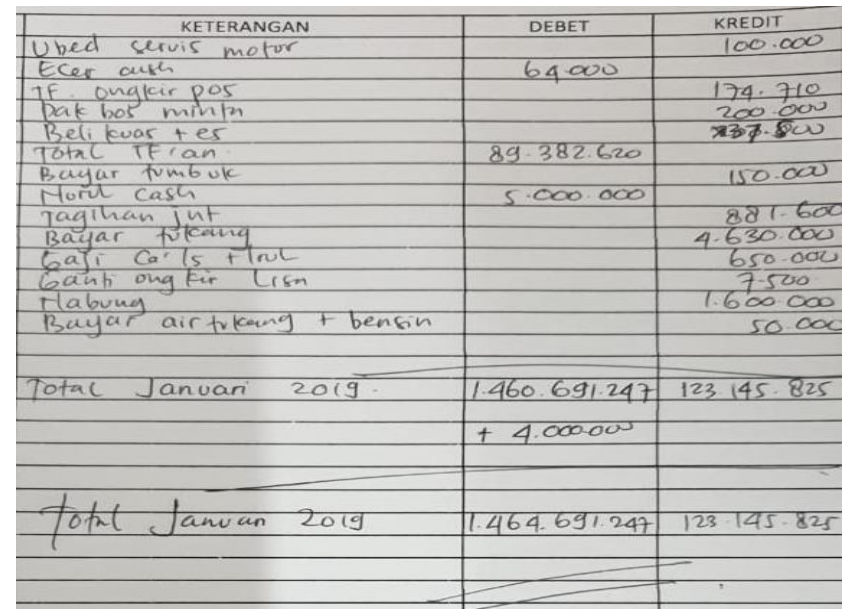

Gambar 4. Laporan Keuangan Daffi bulan Januari 2019

\subsection{Cara Memasarkan Produk dan Komunikasi Pemasaran}

Dalam usahanya menarik konsumen, Daffi Hijab Style juga sering mengadakan promo diskon pada event-event tertentu, juga mengadakan pertemuan bersama member dan customer sebagai bentuk menumbuhkan kepercayaan konsumen terhadap Daffi Hijab Style Lamongan. Daffi Hijab Style memasarkan produk melalui akun facebook, kemudian membuat Fanspage Daffi Hijab Style di Facebook. Saat ini Daffi Hijab Style juga telah memiliki akun Instagram sebagai upaya memaksimalkan media online khususnya jejaring sosial dalam memasarkan produknya.

Konsep dasar dari komunikasi pemasaran yang diterapkan oleh Daffi Hijab Style, yaitu:

a. Produk

Daffi menciptakan kerudung dengan kualitas model, jahitan dan bahan terbaik.

Daffi berusaha menampilkan kepada khalayak, bahwa kerudung Daffi bukanlah kerudung murahan.

b. Harga

Daffi menetapkan kebijakan dalam harga dengan mematok harga sesuai dengan kualitas produk yang dijual Daffi hijab style, dengan harga yang cukup terjangkau dari kisaran Rp 40.000,- sampai dengan Rp 165.000,-.

c. Tempat

Pemilihan pasar online sebagai tempat melakukan transaksi merupakan bagian dari cara Daffi Hijab Style memasarkan produknya. selain pasar online sebagai tempat utama dalam bertransaksi disediakan juga toko fisik, sehingga hal tersebut dapat memberikan nilai tambah bagi Daffi Hijab style dibandingkan dengan toko online yang tidak memiliki toko fisik untuk dapat dikunjungi langsung oleh konsumen. 
d. Promosi

Untuk menarik minat konsumen, Daffi Hijab Style melakukan berbagai bentuk promosi penjualan yaitu program diskon, potongan ongkos kirim, program paket, program keanggotaan, dan program event tertentu, seperti lomba OOTD Daffi Hijab Style, Seminar Shopee, dan Event Gathering Daffi Hijab Style.

e. Packaging (Kemasan)

Untuk menjaga kualitas produknya, Daffi Hijab Style membuat kemasan dengan bahan plastik tebal dan transparan berlogo Daffi, sehingga meskipun produk terbungkus rapi, konsumen masih bisa melihat produk Daffi.

Lebih lanjut Rusdah mengatakan bahwa Daffi Hijab Style dalam komunikasi pemasarannya juga menggunakan Telegram messenger, didalamnya tergabung distributor, agen, dan member, sehingga informasi detail design kerudung dapat diterima secara langsung. Keefektifan komunikasi pemasaran Daffi Hijab dengan menggunakan Telegram dapat digambarkan sebagai berikut:

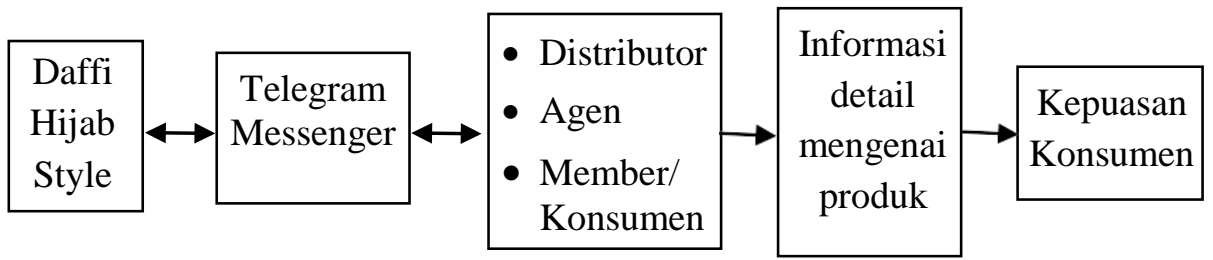

Gambar 5. Proses Pertukaran Informasi Melalui Telegram Messenger

Dari gambar di atas maka dapat dilihat bahwa komunikasi pemasaran yang dilakukan melalui Telegram Messenger menghasilkan kepuasan terhadap produk kerudung Daffi Hijab Style karena dapat berkomunikasi secara langsung, sehingga kesalahpahaman dapat dihindari. Oleh karena itu, Daffi Hijab Style memfokuskan semua detail informasi melalui Telegram Mesenger.

\subsection{Hambatan}

Dalam komunikasi pemasaran, hambatan dapat berupa hambatan fisik dan psikologis. Berdasarkan hasil wawancara yang telah dilakukan, hambatan fisik yang dialami Daffi Hijab Style adalah tidak dapat melakukan tatap muka secara langsung dalam menyampaikan informasi-informasi yang dibutuhkan oleh konsumennya melainkan melalui perantara media internet. Sedangkan hambatan psikologis ialah hambatan yang berhubungan dengan pengalaman dan pengetahuan konsumen. Hambatan psikologis sering dialami oleh Daffi Hijab Style, baik yang berhubungan dengan pengetahuan konsumen tentang bahan kerudung, sampai pada perbedaan penyebutan warna.

Hambatan terbesar dalam komunikasi pemasaran adalah adanya faktor ketidakmampuan komunikan (penerima) menyamakan konsep yang ingin 
disampaikan oleh komunikator (Prisgunanto, 2006). Faktor penyamaan persepsi bergantung pada komunikator. Jadi, gangguan dalam komunikasi bukan hanya disebabkan oleh satu pihak misalnya komunikator atau komunikannya saja, melainkan dari kedua pihak yang terlibat dalam proses komunikasi pemasaran.

\subsection{Proses Pertukaran Informasi}

Dalam konteks pemasaran, proses pertukaran informasi yang dimaksud ialah pertukaran pesan-pesan mengenai produk perusahaan atau informasi mengenai perusahaan itu sendiri. Pertukaran informasi terjadi dalam proses komunikasi antara pengirim pesan (sender) dengan penerima pesan (receiver). Informasi diperoleh baik dari produsen kepada konsumen mengenai produk yang ditawarkan maupun dari konsumen kepada produsen mengenai produk yang diinginkan.

Dalam komunikasi ada empat tipe pesan yaitu pesan yang direncanakan, pesan yang memberi kesimpulan, pesan tentang jaminan mutu, dan pesan yang tidak direncanakan (Machfoedz, 2010). Untuk kegiatan pemasaran di Daffi Hijab Style, pesan dikemas sedemikian untuk membangun kepercayaan dan citra yang baik untuk menarik calon konsumen. Selanjutnya pesan tersebut disampaikan melalui media dan akan menghasilkan umpan balik dari khalayak yang kemudian akan dikelola oleh Daffi Hijab Style untuk mempengaruhi calon konsumen lain. Berikut hasil penelitian mengenai alur kerja proses pertukaran informasi yang terjadi dalam komunikasi pemasaran di Daffi Hijab Style yang merupakan adaptasi dari proses pertukaran informasi dalam komunikasi pemasaran menurut Mahmud Machfoedz:

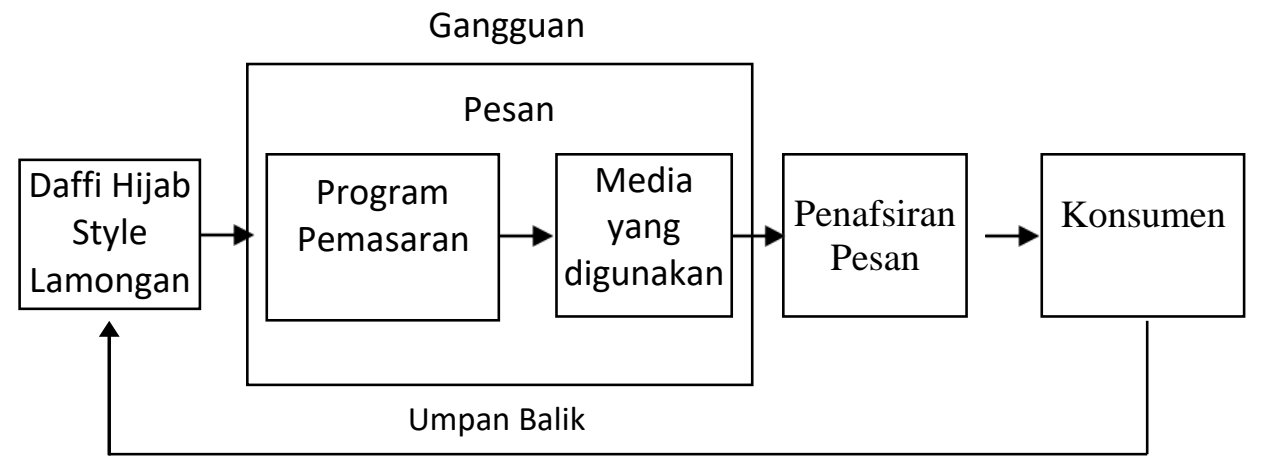

Gambar 6. Proses Pertukaran Informasi di Daffi Hijab Style

\section{KESIMPULAN}

Berdasarkan hasil penelitian mengenai "Komunikasi Pemasaran Online Daffi Hijab Style Lamongan" dapat disimpulkan bahwa dalam melakukan komunikasi pemasaran Daffi Hijab Style memenuhi unsur bauran promosi yakni promosi penjualan yang dilakukan Daffi Hijab Style melalui program diskon, potongan ongkos kirim, program paket, program keanggotaan, dan program event tertentu. Program diskon adalah promosi penjualan yang 
paling efektif dibanding promosi penjualan lainnya yang dilakukan oleh Daffi hijab style. Publisitas diperoleh dari posting konten facebook dan instagram, dan sponsorship event. Pemasaran langsung yang dilakukan Daffi Hijab Style yaitu menyebar broadcast promo melalui aplikasi telegram messenger. Promosi iklan Daffi Hijab Style melalui Facebook Ads, dan posting produk di media sosial yaitu facebook, dan Instagram, juga di website. Dan internet marketing menggunakan media sosial facebook dan instagram, website, aplikasi pesan (Whatsapp dan Telegram) dan sistem agen dan sub agen.

Dalam bauran promosi yang telah dilakukan Daffi Hijab Style dapat diketahui bahwa banyak kegiatan promosi yang dilakukan menggunakan media online. Tiga jenis saluran media online yang paling banyak digunakan Daffi Hijab Style yaitu website, instant messaging dan media sosial facebook dan instagram. Ketiga media online saling berkaitan dan sangat berdampak terhadap keberhasilan promosi dan penjualan produk yang dilakukan Daffi Hijab Style.

Strategi penggunaan media online yang dilakukan oleh Daffi Hijab Style dalam memberikan pelayanan yang maksimal kepada konsumen ialah dengan memberikan informasi produk secara digital berupa real picture (foto nyata) produk yang disebar melalui jejaring sosial, website, Whatsapp dan Telegram Messenger. Format informasi produk, layanan, pembelian, advertising dan informasi event pemasaran, semuanya telah disajikan dalam bentuk digital.

\section{DAFTAR PUSTAKA :}

A. Shimp, Terence. 2003. Periklanan Promosi Aspek Tambahan Komunikasi Pemasaran Terpadu jilid 1. Jakarta: Erlangga

Bulaeng, A.R. 2002. Komunikasi pemasaran. Jakarta: Universitas Terbuka

Iskandar. 2009. Metodologi Penelitian Kualitatif. Jakarta: Gaung Persada Press

Jefkins, Frank. 1995. Periklanan. Jakarta: Erlangga

Kotler, Philip \& Amstrong, Gary. 1997. Prisip-prinsip pemasaran. Jakarta: Erlangga

Kotler, Philip. 2001. Manajemen Pemasaran di Indonesia, Terjemah Herujati Purwoko. Jakarta: Salemba Empat.

Kotler, Philip \& Keller, Kevin Lane. 2009. Manajemen Pemasaran, Terjemah: Benyamin Molan, Edisi 13. Jakarta: PT. Indeks

Kriyantono, Rachmat. 2009. Teknik Praktis Riset Komunikasi Disertai Contoh Praktis Riset Media, Publik Relations, Advertising, Komunikasi Organisasi, Komunikasi Pemasaran Jakarta: Prenada Media Group

Machfoedz, Mahmud. 2010. Komunikasi Pemasaran Modern. Yogyakarta: Cakra Ilmu 
Moleong, Lexy J. 2006. Metodologi Penelitian Kualitatif: Edisi Revisi. Bandung: PT. Remaja Rosdakarya

Morissan \& Wardhany, Corry Andy. 2009. Teori Komunikasi. Jakarta: Ghalia Indonesia.

Morissan, M.A. 2010. Teori Komunikasi Massa: Media, Budaya dan Masyarakat. Bogor: Ghalia Indonesia.

Prisgunanto, Ilham. 2006. Komunikasi Pemasaran : Strategi \& Taktik. Bogor Ghalia Indonesia

Ronny, NF \& Panuju, R. 2018. Digital Media Hospital: Aplikasi Berbasis Daring Komunikasi Pemasaran. Jurnal Komunikasi Profesional, Volume 2 (2): 120-129.

Sutisna. 2002. Perilaku Konsumen dan Komunikasi Pemasaran. Bandung: Remaja Rosdakarya

Tjiptono, Fandy. 1997. Strategi pemasaran. Yogyakarta: Andi.

Zhoriya, Eva Yusuf \& Williams, Lesley. 2007. Manajemen Pemasaran Studi Kasus Indonesia.Jakarta: PPM 